\title{
Evaluation and Isolation of Halophilic Bacteria from the Meyghan Lake in Arak, Iran
}

Farzaneh Mohammadzadeh Rostami
(PhD)
Faculty of Medicine, Isfahan
University of Medical Sciences,
Isfahan, Iran
Milad Shahsafi (PhD)
Department of Microbiology, Science
Faculty, Islamic Azad University of Arak,
Arak, Iran
Corresponding author: Milad Shahsafi
Tel: +989122807261
Email: Milad.shahsafiii@gmail.com
Address: Islamic Azad University of
Arak, Arak, Iran
Received: 23 May 2018
Revised: 08 Ju1 2018
Accepted: 08 Jul 2018

\section{ABSTRACT}

Background and Objectives: Halophilic bacteria can grow and survive in environments with a wide range a wide range of salinities. In this study, we aimed to isolate halophilic bacteria from the Meyghan Lake in Arak (Iran) and evaluate their enzymatic activity.

Methods: Samples were taken from four different areas of the lake. Halophilic bacteria were isolated by culture in moderate halophilic medium, sea water nutrient agar and nutrient agar containing different salt concentrations. Purification was done via consecutive culture methods, and production of extracellular hydrolytic enzymes including amylase, protease, lecithinase, DNase and lipase was evaluated.

Results: Among 74 bacteria isolated from the lake water samples, 24 produced amylase, 27 produced lipase (Tween 40 and 00 ), 60 produced protease, three produced DNase and 61 produced lecithinase.

Conclusion: In this study, we isolated halophilic bacteria with enzymatic activity and potential industrial applications.

Keywords: Biological Diversity, isolation and purification, Halobacteriales, Meyghan Lake, Arak.

This paper should be cited as: Mohammadzadeh Rostami F, Shahsafi M[Evaluation and Isolation of Halophilic Bacteria from the Meyghan Lake in Arak, Iran]. ml.jgoums. 2018; 12(6):34-39 


\section{INTRODUCTION}

The phylogenetic and metabolic diversity of halophilic microorganisms is astonishing (1). In recent years, halophilic microorganisms have been extensively studied for their biotechnological potential (2). Enzymes produced by halophilic microorganism are intrinsically stable and active at high salt concentrations, and can be used for various purposes, such as food processing, environmental bioremediation and biosynthesis (3, 4). Moreover, extracellular hydrolytic enzymes such as amylase, protease, lipase, DNase, pullulanase and xylanase have been used in the food industry, biomedical sciences and chemical industry (5).

Today, a combination of culture, molecular and chemotaxonomic methods is used to unravel information about halophilic microorganisms (5). Various microorganisms, including bacteria and archaea, are found in salty environments. These microorganisms have adapted to living in environments with high salt concentrations and high osmotic pressure (6). Enzymes found in nature have long been used in the production of food products such as cheese, juice and wine, and in the manufacture of goods such as leather and linen (7). With the advent of fermentation processes, particular attention has been paid to the production of industrial enzymes. Such enzymes can be used in the production of detergents, textiles, paper, starch, organic compounds, leather, food and drugs (8). Majority of commonly used enzymes are hydrolytic, which can decompose different natural materials. Proteases, amylases, cellulases, xylanases, pectinases, inulinases and lipases are among the most important hydrolytic enzymes used in various industries. In the absence of salt, these enzymes can maintain more than $30 \%$ of their activity (9). The Meyghan Lake is the last ecological ring in the Arak basin plain, which absorbs surface waters of seasonal meadows. The lake has an area of $100-110 \mathrm{Km}^{2}$ depending on its inlet water. The main goal of microbial ecology is to understand microbial diversity in natural habitats. This study aimed to study the biodiversity of halophilic bacteria in the Meyghan Lake in Arak, Iran.

\section{MATERIALS AND METHODS}

In this descriptive cross-sectional study, sampling was carried out from the Meyghan Lake in February 2009. Overall, 100 samples were collected from a depth of $30-50 \mathrm{~cm}$ and from different areas of the lake, and then transferred to the laboratory in sterile glasses containers. In addition, salt samples of that area were collected. Other characteristics of the samples including temperature and $\mathrm{pH}$ as well as geographical characteristics of the relevant points were recorded. The samples were transferred to the laboratory for measuring $\mathrm{pH}$ and salinity. Moderate halophilic medium (12\% salt) and seawaternutrient agar (3\% salt) were used for isolation of moderately halophilic bacteria (8). The medium was prepared with various salt percentages $(0,3,5,7.5,10,15$ and $20 \%)$ and $\mathrm{pH}$ of 7. All media were autoclaved at $15 \mathrm{psi}$ and $121{ }^{\circ} \mathrm{C}$. The concentration of salt at which optimum growth was observed after 12 hours was recorded. Isolates were identified by morphological assessment, gram staining, catalase test and oxidative test (9).

The conditions of the media used in this study were selected based on climatic conditions of the Meyghan Lake and requirements of different bacterial species. Table 1 shows the components of the culture media used for isolation of halophilic bacteria.

The isolates were screened based on the ability to produce extracellular enzymes including amylase, DNase, lipase and protease.

Regression analysis was performed to obtain the correlation between variables previously verifying normality and variance homogeneity. Statistical analysis was done using SPSS (version 18).

\section{RESULTS}

Presence of the cations in water was evaluated using anatomic absorption spectrophotometer (AAnalyst 100, PerkinElmer). The amount of chlorine anions, sulfate anion and carbonate was measured by titration. Table 2 shows the concentration of some important anions and cations in the Meyghan Lake. 
Table 1- Components of the culture media used for isolation of halophilic bacteria

\begin{tabular}{|c|c|c|c|}
\hline \multirow{2}{*}{\begin{tabular}{|c|} 
Medium \\
Moderate halophilic medium \\
\end{tabular}} & \multirow{2}{*}{$\begin{array}{r}\text { pH } \\
\\
7.5 \\
\end{array}$} & \multicolumn{2}{|c|}{$\begin{array}{l}\text { Components/ingredients of the culture } \\
\text { media }(\mathrm{g} / \mathrm{L})\end{array}$} \\
\hline & & $\mathrm{NaCl}$ & 101 \\
\hline & & $\mathrm{MgCl}_{2} \cdot 6 \mathrm{H}_{2} \mathrm{O}$ & 7 \\
\hline & & $\mathrm{MgSO}_{4} \cdot 7 \mathrm{H}_{2} \mathrm{O}$ & 9.6 \\
\hline & & $\mathrm{CaCl}_{2} \cdot 2 \mathrm{H}_{2} \mathrm{O}$ & 0.36 \\
\hline & & $\mathrm{KCl}$ & 2 \\
\hline & & $\mathrm{NaHCO}_{3}$ & 0.06 \\
\hline & & $\mathrm{NaBr}$ & 0.026 \\
\hline & & Yeast Extract & 10 \\
\hline & & Peptone & 5 \\
\hline & & Glucose & 1 \\
\hline & & Agar & 15 \\
\hline \multirow[t]{8}{*}{ Modified growth medium } & & $\mathrm{NaCl}$ & 183.9 \\
\hline & 7.5 & $\mathrm{MgCl}_{2} \cdot 6 \mathrm{H}_{2} \mathrm{O}$ & 22.9 \\
\hline & & $\mathrm{MgSO}_{4} .7 \mathrm{H}_{2} \mathrm{O}$ & 26.8 \\
\hline & & $\mathrm{CaCl}_{2} \cdot 2 \mathrm{H}_{2} \mathrm{O}$ & 2.95 \\
\hline & & $\mathbf{K C l}$ & 5.36 \\
\hline & & Yeast Extract & 2 \\
\hline & & Peptone & 10 \\
\hline & & Agar & 15 \\
\hline \multirow[t]{9}{*}{ Sea water nutrient agar } & & Peptone from meat & 5 \\
\hline & 7.5 & Yeast Extract & 1 \\
\hline & & Meat Extract & 2 \\
\hline & & $\mathrm{NaCl}$ & 20 \\
\hline & & $\mathrm{MgSO}_{4} \cdot 7 \mathrm{H}_{2} \mathrm{O}$ & 5 \\
\hline & & $\mathrm{MgCl}_{2} \cdot 6 \mathrm{H}_{2} \mathrm{O}$ & 3 \\
\hline & & KCl & 0.5 \\
\hline & & $\mathrm{CaCl}_{2}$ & 0.05 \\
\hline & & Agar & 15 \\
\hline
\end{tabular}

Table 2- Concentration of some anions and cations in Mevghan Lake

\begin{tabular}{cc}
\hline Ion & Concentration $(\mathrm{mg} / \mathrm{L})$ \\
\hline $\mathrm{Na}^{+}$ & 80000 \\
$\mathrm{Ca}^{++}$ & 425 \\
$\mathrm{Mg}^{++}$ & 5304.1 \\
$\mathrm{~K}^{+}$ & \\
$\mathrm{Cl}^{-}$ & 1650 \\
$\mathrm{HCO3}^{-}$ & 171046.25 \\
$\mathrm{SO}^{-6}$ & 762.5 \\
$\mathrm{Fe}++$ & 1344 \\
\hline
\end{tabular}


37/ Mohammadzadeh Rostami and Shahsafi

Table 3- Activity of lecithinase, DNase, protease, lipase (tween 40 and 80) and amylase in the 74 bacteria isolated from the water samples

\begin{tabular}{|c|c|c|c|c|c|c|}
\hline Isolate & Amylase & $\begin{array}{c}\text { Lipase } \\
(\text { tween 80) }\end{array}$ & $\begin{array}{c}\text { Lipase } \\
(\text { tween 40) }\end{array}$ & Protease & DNase & Lecithinase \\
\hline N1 & - & - & - & + & - & + \\
\hline N2 & - & - & - & + & - & + \\
\hline N3 & - & - & - & + & - & + \\
\hline $\mathrm{N} 4$ & + & - & - & + & - & + \\
\hline N5 & - & - & - & + & - & + \\
\hline N6 & - & - & - & + & - & + \\
\hline N7 & - & - & - & + & - & + \\
\hline N8 & - & - & - & + & - & + \\
\hline N9 & + & + & + & + & - & + \\
\hline N10 & - & - & - & + & - & + \\
\hline N11 & - & - & - & + & - & + \\
\hline N12 & - & - & - & + & - & + \\
\hline N13 & + & - & - & + & - & + \\
\hline N14 & - & - & - & - & - & - \\
\hline N15 & - & - & - & + & - & + \\
\hline N16 & - & - & - & + & - & + \\
\hline N17 & - & - & - & + & - & + \\
\hline N18 & + & + & + & + & - & + \\
\hline N19 & + & + & - & + & - & + \\
\hline N20 & + & + & + & + & - & + \\
\hline N21 & - & - & - & + & - & + \\
\hline N22 & + & - & - & + & + & + \\
\hline $\mathrm{N} 23$ & + & + & + & + & - & + \\
\hline $\mathrm{N} 24$ & - & - & - & - & - & - \\
\hline $\mathrm{N} 25$ & - & - & - & + & - & + \\
\hline $\mathrm{N} 26$ & + & - & - & + & - & + \\
\hline N27 & - & - & - & - & - & - \\
\hline $\mathrm{N} 28$ & - & - & - & - & - & - \\
\hline N29 & + & + & - & + & - & + \\
\hline N30 & - & - & - & - & - & - \\
\hline N31 & - & - & - & + & - & + \\
\hline $\mathrm{N} 32$ & - & - & - & + & - & + \\
\hline $\mathbf{N} 33$ & + & - & - & + & + & + \\
\hline N34 & - & - & - & - & - & - \\
\hline N35 & - & - & - & + & - & + \\
\hline $\mathrm{N} 36$ & - & - & - & + & - & + \\
\hline N37 & + & + & + & + & - & + \\
\hline N38 & + & + & + & + & - & + \\
\hline N39 & - & - & - & + & - & + \\
\hline $\mathbf{N} 40$ & - & - & - & + & - & + \\
\hline N41 & + & + & - & + & - & + \\
\hline $\mathbf{N} 42$ & - & - & - & + & - & + \\
\hline $\mathrm{N} 43$ & + & + & - & + & - & + \\
\hline $\mathrm{N} 44$ & + & + & + & + & - & + \\
\hline $\mathrm{N} 45$ & - & - & - & + & - & + \\
\hline $\mathrm{N} 46$ & - & - & - & + & - & + \\
\hline N47 & - & - & - & + & - & + \\
\hline $\mathrm{N} 48$ & + & + & + & + & - & + \\
\hline N49 & - & - & - & + & - & + \\
\hline N50 & - & - & - & + & - & + \\
\hline N51 & - & - & - & + & - & + \\
\hline N52 & + & + & - & + & - & + \\
\hline N53 & - & - & - & + & - & + \\
\hline N54 & - & - & - & + & - & + \\
\hline N55 & - & - & - & + & - & + \\
\hline N56 & - & - & - & + & - & - \\
\hline N57 & - & - & - & + & - & + \\
\hline N58 & + & + & - & + & + & - \\
\hline N59 & - & - & - & + & - & + \\
\hline N60 & - & - & - & + & - & + \\
\hline N61 & + & + & - & + & - & + \\
\hline N62 & - & - & - & + & - & - \\
\hline N63 & - & - & - & + & - & + \\
\hline N64 & - & - & - & + & - & + \\
\hline N65 & - & - & - & + & - & + \\
\hline N66 & - & - & - & + & - & - \\
\hline N67 & + & + & - & + & - & + \\
\hline N68 & - & - & - & + & - & + \\
\hline N69 & + & + & - & + & - & - \\
\hline N70 & - & - & - & + & - & + \\
\hline N71 & + & + & - & + & - & - \\
\hline N72 & - & - & - & + & - & + \\
\hline N73 & + & + & - & + & - & + \\
\hline N74 & - & - & - & + & - & - \\
\hline
\end{tabular}


Figure 1- Image of culture plates showing protease activity (A), amylase activity (B), lipase activity (C) and DNase activity (D)

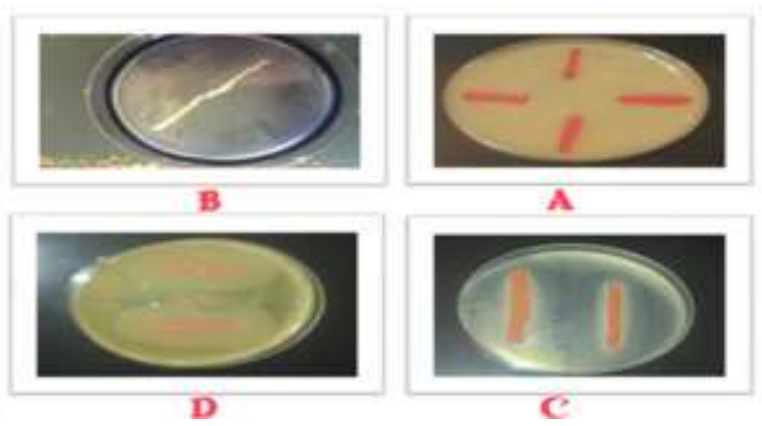

\section{DISCUSSION}

Our results showed that the Meyghan Lake might be a source of halophilic bacteria that can be used for production of new drugs and other bioactive compounds. Due to the ability to grow in hypersaline environments, halophilic microorganisms have great biotechnological potential (9-11). For example, bacteriorhodopsin is used in holography .In the Far East, halophilic microorganisms are also used for producing traditional brews, such as fish sauce and soy sauce (6). New enzymes and biocatalysts are continuously being developed to be used in paper, textile and food industries $(13,14)$. Protein engineering lead to increasing the enzymes efficiency and will deploy their department because increases the compatibility capacities in existing case of processes (15). As mentioned previously, hydrolase enzymes are an important group of microbial enzymes with various industrial applications (16-18). Proteases, amylase, lipase and cellulose are important for production of laundry detergents. Proteases are also used in the production of milk and fruit juice (17). Chitins enzyme can be utilize for biological control of fungal pathogens. Moreover, DNase enzyme can be used to detect contamination of hospital settings with certain pathogenic bacteria, and for quality control of food.

Halophilic microorganisms were first investigated as contaminants of salty foods, but later studies on their structure and physiology elucidated the great potential of these microorganisms in biotechnology (19).

Since industrial processes create unique and extreme physical and chemical conditions, identification of enzymes capable of tolerating or adapting to such conditions is of upmost importance $(18,20)$. The majority of microorganisms that are able to produce such enzymes has simple nutritional requirements and is able to use various compounds as sources of energy $(16,20)$.

\section{CONCLUSION}

The Meyghan Lake in Arak has a more unique environment compared to other salty wetlands of Iran. Unlike other salty lakes in Iran, the main salts in the Meyghan Lake are sodium chloride and sodium sulfate. In this study, we isolated halophilic bacteria with enzymatic activity and potential industrial applications. Among the 74 bacteria isolated from the lake water samples, 24 produced amylase, 27 produced lipase (Tween 40 and 80), 68 produced protease, three produced DNase and 61 produced lecithinase.

\section{ACKNOWLEDGEMENTS}

The authors would like to express their sincere gratitude to staff of the Islamic Azad University of Arak for their cooperation.

\section{CONFLICT OF INTEREST}

The authors declare that there is no conflict of interest. 


\section{REFERENCES}

1. Oren A. Diversity of halophilic microorganisms: environments, phylogeny, physiology, and applications. J Ind Microbiol Biotechnol. 2002; 28(1): 56-63. 2002; 28(1): 56-63.

2. Mellado E, Ventosa A. Biotechnological potential of moderately and extremely halophilic microorganisms. Microorganisms for health care. food and enzyme production. 2003: 233-56.

3. Zhang T, Datta S, Eichler J, Ivanova N, Axen SD, Kerfeld CA, Chen $\mathrm{F}$, et al. Identification of a haloalkaliphilic and thermostable cellulase with improved ionic liquid tolerance. Green Chemistry. 2011; 13(8): 2083-90.

4. de Lourdes Moreno M, Pérez D, García MT, Mellado E. Halophilic bacteria as a source of novel hydrolytic enzymes. Life. 2013 Jan 10;3(1):38-51.

5. Ma Y, Galinski EA, Grant WD, Oren A, Ventosa A. Halophiles 2010: life in saline environments. Applied and environmental microbiology. 2010; 76(21): 6971-81.

6. Oren A. Diversity of halophilic microorganisms: environments, phylogeny, physiology, and applications. Journal of Industrial Microbiology and Biotechnology. 2002; 28(1): 56-63.

7. Antón J, Rosselló-Mora R, Rodríguez-Valera F, Amann R. Extremely halophilic bacteria in crystallizer ponds from solar salterns. Applied and Environmental Microbiology. 2000; 66(7): 3052-7.

8. Asad S, Amoozegar MA, Pourbabaee A, Sarbolouki MN, Dastgheib SM. Decolorization of textile azo dyes by newly isolated halophilic and halotolerant bacteria. Bioresource technology. 2007; 98(11): 2082-8.

9. Hutcheon GW, Vasisht N, Bolhuis A. Characterisation of a highly stable $\alpha$-amylase from the halophilic archaeon Haloarcula hispanica. Extremophiles. 2005; 9(6): 487-95.

10. Oie CS, Albaugh CE, Peyton BM. Benzoate and salicylate degradation by Halomonas campisalis, an alkaliphilic and moderately halophilic microorganism. Water research. 2007; 41(6): 1235-42.

11. Waditee-Sirisattha R, Kageyama H, Takabe $\mathrm{T}$. Halophilic microorganism resources and their applications in industrial and environmental biotechnology. AIMS Microbiol. 2016; 2: 42-54. DOI: 10.3934/microbiol.2016.1.42
12. Margesin R, Schinner F. Potential of halotolerant and halophilic microorganisms for biotechnology. Extremophiles. 2001; 5(2): 73-83.

13. Yin J, Chen JC, Wu Q, Chen GQ. Halophiles, coming stars for industrial biotechnology. Biotechnol Adv. 2015; 33(7): 1433-42. doi: 10.1016/j.biotechadv.2014.10.008.

14. Chen GQ, Jiang XR. Next generation industrial biotechnology based on extremophilic bacteria. Current opinion in biotechnology. 2018; 50: 94-100.

15. Dalmaso GZ, Ferreira D, Vermelho AB. Marine extremophiles: a source of hydrolases for biotechnological applications. Mar Drugs. 2015; 13(4): 1925-1965. doi: 10.3390/md13041925.

16. Zou H, Chen N, Shi M, Xian M, Song Y, Liu J. The metabolism and biotechnological application of betaine in microorganism. Applied microbiology and biotechnology. 2016; 100(9): 3865-76. doi: 10.1007/s00253-016-7462-3.

17. Kashyap P, Sabu A, Pandey A, Szakacs G, Soccol CR. Extra-cellular L-glutaminase production by Zygosaccharomyces rouxii under solid-state fermentation. Process Biochemistry. 2002; 38(3): 30712.

18. Karbalaei-Heidari HR, Amoozegar MA, Hajighasemi M, Ziaee AA, Ventosa A. Production, optimization and purification of a novel extracellular protease from the moderately halophilic bacterium Halobacillus karajensis. Journal of industrial microbiology \& biotechnology. 2009; 36(1): 21-7. doi: 10.1007/s10295008-0466-y.

19. Oie CS, Albaugh CE, Peyton BM. Benzoate and salicylate degradation by Halomonas campisalis, an alkaliphilic and moderately halophilic microorganism. Water research. 2007; 41(6): 1235-42. DOI:10.1016/j.watres.2006.12.029.

20. Calegari-Santos R, Diogo RA, Fontana JD, Bonfim TM. Carotenoid production by halophilic archaea under different culture conditions. Current microbiology. 2016; 72(5): 641-51. doi: 10.1007/s00284-015-0974-8. 